\title{
ROLE OF TEMPERATURE IN THE PRODUCTION OF THE L.E. (LUPUS ERYTHEMATOSUS) CELL PHENOMENON
}

\author{
BY \\ G. BENCZE AND L. LAKATOS \\ WITH THE TECHNICAL ASSISTANCE OF \\ K. HANSAGI \\ First Department of Medicine University Medical School, Szeged, Hungary
}

In previous experiments dealing with the two types of L.E. plasma factor we found that the transferable (stable) type did not become inactivated, even when heated at $65^{\circ} \mathrm{C}$. for $60 \mathrm{~min}$. In plasma transfer experiments carried out on dogs we succeeded in producing L.E. cells by means of a stable type of plasma factor kept at $56^{\circ} \mathrm{C}$. for $60 \mathrm{~min}$., whereas the non-transferable (labile) type of plasma factor became inactivated when heated at $56^{\circ} \mathrm{C}$. for $30 \mathrm{~min}$. (Bencze, 1960). Hence this labile type of L.E. factor is relatively more sensitive to heat, and the experiments performed so far suggest that the labile type occurs far more frequently.

It is generally accepted that after various forms of traumatization the cells must be kept for at least $30 \mathrm{~min}$. at $37^{\circ} \mathrm{C}$., but Ogryzlo (1958) reported that L.E. cells also developed at room temperature $\left(22^{\circ} \mathrm{C}\right.$.). The present paper deals with the effect of different temperatures on the development of the L.E.-cell phenomenon in vitro.

\section{Method}

The L.E.-cell test was carried out by the rotatory method of Zinkham and Conley (1956) using blood from the same patient at three temperatures: $37^{\circ} \mathrm{C} ., 20-22^{\circ} \mathrm{C}$., and $4^{\circ} \mathrm{C}$. The time of incubation in each case was $90 \mathrm{~min}$., as this had been found most suitable for the development of L.E. cells in previous experiments.

\section{Material}

Simultaneous L.E.-cell tests were performed repeatedly (on 220 occasions in all) on 45 patients ( 21 with L.E.-cell positive systemic lupus erythematosus, and 24 others with rheumatoid arthritis, discoid erythematosus, and Sjögren's disease).

\section{Results}

In previous communications (Bencze and Lakatos, $1960,1962)$ we have reported that, by the usual methods with the labile type of L.E. factor, L.E. cells often failed to appear even with the patient's own leukocytes. With the stable type of L.E. factor, however, L.E. cells could be demonstrated regularly every week for years.

In the 24 patients with diseases other than systemic lupus erythematosus, L.E. cells could not be found at all at any temperature.

The results in the 21 patients with L.E.-cell positive S.L.E. are shown in the Table. It was observed that in nineteen of these 21 patients the L.E. factor was labile and in two it was stable.

TABLE

RESULTS OF SIMULTANEOUS L.E.-CELL EXAMINATIONS CARRIED OUT AT DIFFERENT TEMPERATURES FOR 90 MINUTES

\begin{tabular}{|c|c|c|c|c|}
\hline \multirow{2}{*}{\multicolumn{2}{|c|}{ L.E.-cell Phenomenon }} & \multicolumn{3}{|c|}{ Temperature $\left({ }^{\circ} \mathrm{C}.\right)$} \\
\hline & & \multirow{2}{*}{$\begin{array}{l}37 \\
15\end{array}$} & \multirow{2}{*}{$\frac{20-22}{18}$} & \multirow{2}{*}{$\begin{array}{r}4 \\
16\end{array}$} \\
\hline Positive & . & & & \\
\hline Negative & .. & 6 & 3 & 5 \\
\hline Total No. & atients .. & 21 & 21 & 21 \\
\hline
\end{tabular}

The results obtained establish that the L.E.-cell phenomenon occurs not only at $37^{\circ} \mathrm{C}$. but also at room temperature, and even at $4^{\circ} \mathrm{C}$. The number of L.E. cells, compared with the total number of leucocytes, was about the same at all temperatures. The L.E.-cell phenomenon was negative in six out of the 21 cases at $37^{\circ} \mathrm{C}$., in only three at $20-22^{\circ} \mathrm{C}$., and in five at $4^{\circ} \mathrm{C}$.

\section{Summary}

In 21 patients with systemic lupus erythematosus, repeated L.E.-cell examinations were carried out simultaneously for $90 \mathrm{~min}$. at three incubation temperatures. The results show that the L.E.-cell phenomenon occurs not only at $37^{\circ} \mathrm{C}$., but also at $20-22^{\circ} \mathrm{C}$. and at $4^{\circ} \mathrm{C}$. 


\section{REFERENCES}

Bencze, G. (1960). Ann. rheum. Dis., 19, 272. and Lakatos, L. (1960). Brit. med. J., 2, 1571. (1962). Acta rheum. scand., 8, 52.

Ogryzlo, M. A. (1958). In "Progress in Arthritis", ed. J. H. Talbott and L. M. Lockie, p. 372 . Grune and Stratton, New York.

Zinkham, W. H., and Conley, C. L. (1956). Bull. Johns Hopk. Hosp., 98, 102.

Rôle de la température sur la production du phénomène L.E. (lupus érythémateux)

\section{RÉSUMÉ}

Chez 21 malades atteints de lupus érythémateux disséminé des examens répétés des cellules L.E. furent effectués simultanément pendant 90 minutes à trois températures d'incubation. Les résultats de ces expériences montrent que le phénomène L.E. se produit non seulement à la température de $37^{\circ} \mathrm{C}$. mais aussi à celles de $20^{\circ}-22^{\circ} \mathrm{C}$. et de $4^{\circ} \mathrm{C}$.

\section{El papel de la temperatura en la producción del fenómeno L.E. (lupus eritematoso)}

\section{SUMARIO}

En 21 enfermos con lupus eritematoso diseminado exámenas repetidos de células L.E. se hicieron al mismo tiempo durante 90 minutos en tres temperaturas de incubación. Los resultados de esta investigación demuestran que el fenómeno L.E. se produce no sólo a la temperatura de $37^{\circ} \mathrm{C}$. sino también a las de $20^{\circ}-22^{\circ} \mathrm{C}$. $y$ de $4^{\circ} \mathrm{C}$. 